\title{
Molecular Characterization of a Novel Begomovirus Infecting Malva (Gaya guerkeana K. Schum.)
}

\author{
Mayra Machado de Medeiros Ferro'; Arthur Alencar Raposo Tenório'; \\ Sarah Jacqueline Cavalcanti da Silva'; Janaíne Rossane Araújo Silva'; Roberto Ramos-Sobrinhol*; \\ Gaus Silvestre de Andrade Lima'; Iraildes Pereira Assunção'*
}

'Setor de Fitossanidade/Centro de Ciências Agrárias, Universidade Federal de Alagoas, Rio Largo, AL, Brazil, 57100-000 *Corresponding authors: R. Ramos-Sobrinho, e-mail: cbrobertorsb@hotmail.com I.P. Assunção, e-mail: iraildes.assuncao@ceca.ufal.br

\begin{abstract}
The genus Begomovirus (family Geminirvidae) comprises circular single-stranded DNA viruses that infect both cultivated and non-cultivated hosts, being transmitted by the insect vector Bemisia tabaci (Gennadius) (Hemiptera: Aleyrodidae). This study aimed to conduct the molecular characterization of a novel begomovirus infecting the non-cultivated plant Gaya guerkeana K. Schum. (Malvaceae). A leaf sample of G. guerkeana was collected in the State of Pernambuco, Brazil, in 2010. Viral genomic components were amplified via RCA, cloned, and commercially sequenced. The full-length DNA-A sequence was used for phylogenetic analysis and pairwise comparisons with other previously reported begomoviruses. The begomovirus DNA-A from $G$. guerkeana was most closely related to the Sida mottle Alagoas virus (SiMoAV, JX871386), having $84.8 \%$ nucleotide identity. Using the $\geq 91 \%$ identity criteria for DNA-A established by the Geminivirus Study Group of the International Committee on Taxonomy of Viruses, this isolate was considered a putative new begomovirus species, and the name Gaya yellow mosaic virus (GaYMV) is suggested. The GaYMV isolate grouped with SiMoAV and other begomoviruses infecting Sida spp. from the State of Alagoas, Brazil. This is the first report of a begomovirus infecting G. guerkeana, indicating that this non-cultivated plant can act as a reservoir/source of begomoviruses.
\end{abstract}

Keywords: alternative host, Gaya guerkeana, geminivirus, phylogeny

The family Geminiviridae encompasses several species of phytoviruses that have a genome composed of circular single-stranded DNA (ssDNA) encapsidated in geminated quasi-icosahedral particles (Brown et al., 2012). The family consists of the genera Becurtovirus, Begomovirus, Capulavirus, Curtovirus, Eragrovirus, Grablovirus, Mastrevirus, Topocuvirus and Turncurtovirus, classified according to insect vector type, host range, genomic organization and phylogenetic relationship (Varsani et al., 2017; Zerbini et al., 2017). Begomoviruses are transmitted by the whitefly Bemisia tabaci (Gennadius) (Hemiptera: Aleyrodidae) and are widely spread in tropical and subtropical regions, where they are considered a limiting factor for the production of economically important crops (Morales, 2010; Navas-Castillo et al., 2011). In Brazil, bean (Phaseolus spp.) and tomato (Solanum lycopersicon L.) crops are the most severely affected (Morales, 2010; Navas-Castillo et al., 2011).

Besides infecting cultivated plants, begomoviruses are found in a wide range of wild/ non-cultivated hosts, especially those belonging to the families Malvaceae, Euphorbiaceae, and Fabaceae (Morales, 2010). Non-cultivated plants may act as alternative begomovirus hosts when cultivated species do not exist in the field or as a source of novel begomoviruses that arise 
via recombination in cases of mixed infections (Barreto et al., 2013; Rocha et al., 2013).

In this context, this work aimed at the molecular characterization of a novel begomovirus infecting the non-cultivated plant Gaya guerkeana.

A leaf sample of $G$. guerkeana presenting symptoms indicative of begomovirus infection (yellowing and mosaic) was collected in Caruaru, Pernambuco (PE) in 2010 (Figure 1), and the total DNA was extracted from plant tissue, according to the protocol described by Doyle \& Doyle (1987). Viral genomic components were amplified via Rolling Circle Amplification (RCA) according to the method described by InoveNagata et al., (2004). Aliquots of the amplification were individually submitted to cleavage through BamHI and Hind Ill endonucleases. The products of the cleavage reactions containing fragments of approximately 2600 nucleotides, corresponding to one copy of each genomic component, were used for binding to the pBluescript KS+ vector (Stratagene), previously linearized through the same enzyme and dephosphorylated. Potential recombinant plasmids were used to transform ultracompetent cells of Escherichia coli DH5a strain by the heat shock method. The obtained clones were commercially sequenced via primer walking.

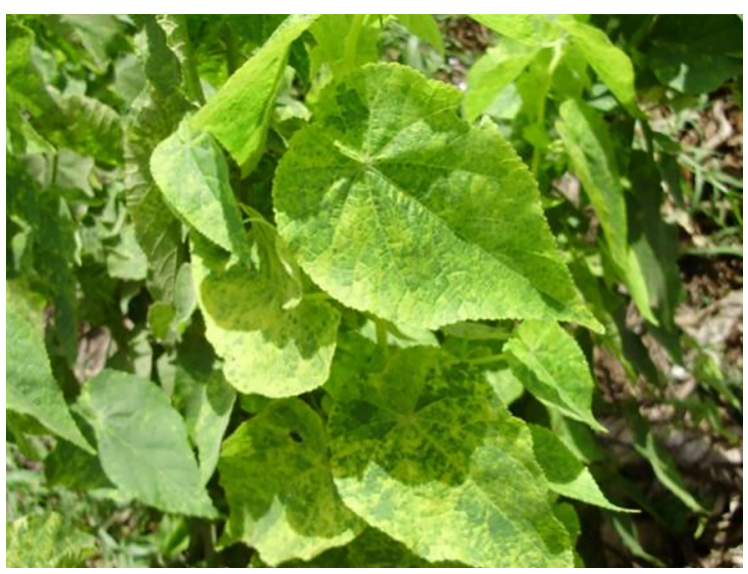

Figure 1. Mosaic symptoms in Gaya guerkeana K. Schum. (Malvaceae) infected with the Gaya yellow mosaic virus (GaYMV), a putative new begomovirus.

Contigs of the complete viral genomic component were assembled using the DNAMAN software version 6 (Lynnon Biosoft Corporation). The obtained sequence was initially analyzed through the BLASTn algorithm and the non- redundant nucleotide database GenBank to determine the viral species with the highest percentage of sequence identity. Similar sequences from GenBank were used for species demarcation of the novel begomovirus isolate using the Sequence Demarcation Tool v. 1.2 (Muhire et al., 2013).

Multiple nucleotide sequence alignments for the DNA-A dataset of the G. guerkeana isolate and other begomoviruses from Brazil were prepared using the MUSCLE algorithm and manually adjusted in the MEGA6 package (Tamura et al., 2013). Bayesian Inference for DNA-A was performed on the CIPRES web portal (https://www.phylo.org/) using MrBayes v. 3.2.3 (Ronquist et al., 2012). The GTR+G+l model of evolution was used for the GaYMV DNA-A dataset. The analysis was run for 10 million generations using four chains and sampling at every 1,000 generations for a total of 10,000 trees. The first 2,500 trees were discarded as a burn-in phase. Posterior probabilities (Rannala \& Yang, 1996) were determined from a consensus tree majorityrule generated with the 7,500 remaining trees. Trees were viewed and edited using the software FigTree v. 1.4 (ztreebio.ed.acuk/software/figtree) and Inkscape (https://inkscape.org/pt/).

A clone (BR-Car1-12A) was obtained from the $G$. guerkeana sample collected in Caruaru (PE). BLASTn analysis showed that the genomic component corresponded to DNA-A. Using pairwise comparisons and the $\geq 91 \%$ identity criteria for complete DNA-A sequences established by the Geminiviridae Study Group of International Committee on Taxonomy of Viruses (ICTV) for the demarcation of species within the Begomovirus genus (Brown et al., 2015), the clone obtained herein was classified as a putative new species of Begomovirus. BR-Car1-12A was more closely related to the Sida mottle Alagoas virus (SiMoAV, JX871386), displaying an 84.8\% nucleotide identity, and the name Gaya yellow mosaic virus (GaYMV) is proposed.

GaYMV presented a genomic organization typical of New World begomoviruses, with five ORFs in DNA-A. The conserved nonanucleotide (5' TAATATT/AC 3') was detected in the common region, which is part of the stem-loop that contains the viral 
replication origin. We also identified repeated GGGGG/GGGGG sequences (iterons), which are essential to initiate viral replication.

In the Bayesian phylogenetic tree, GaYMV grouped with SiMoAV, Sida mosaic Alagoas virus (SiMAV), and Sida yellow blotch virus (SiYBV), all obtained from Sida spp. from the State of Alagoas (Tavares et al., 2012; Wyant et al., 2012) (Figure 2). These results agree with those found in pairwise comparison analysis, in which the BR-Car1-12A isolate has a higher identity percentage with the SiMOAV species.

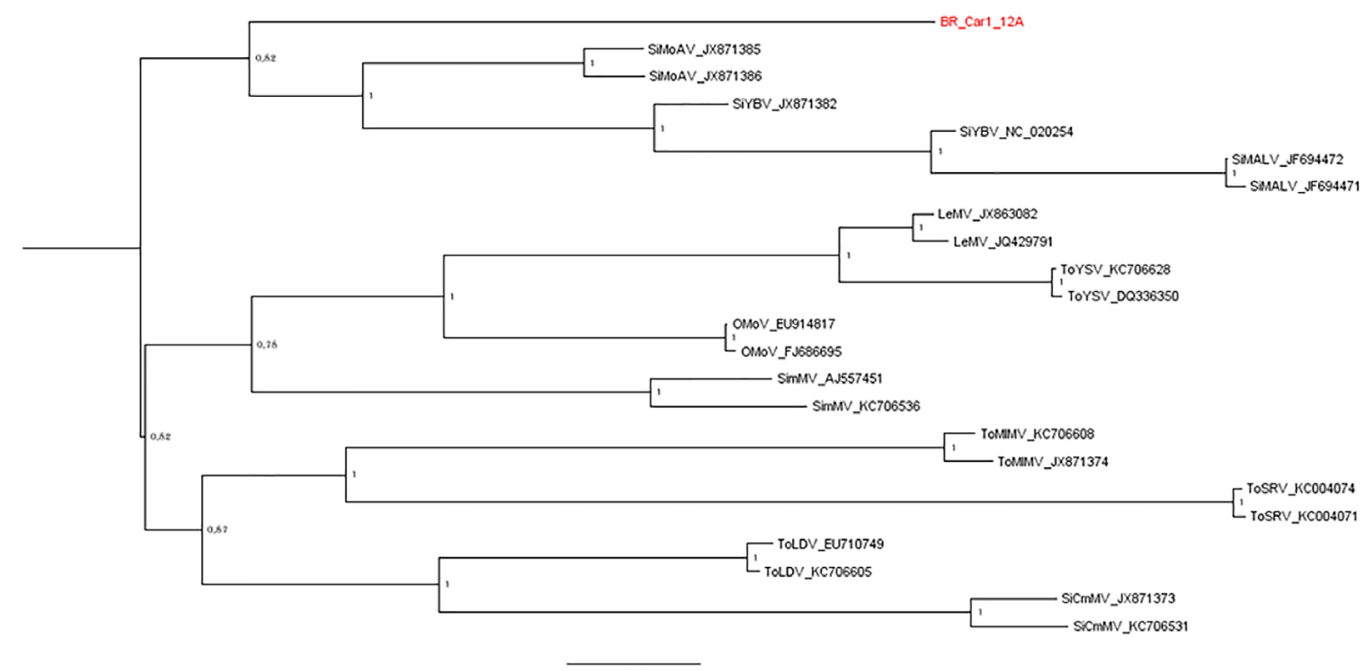

Figure 2. Phylogenetic analysis of Bayesian inference based on DNA-A from the Gaya yellow mosaic virus (GaYMV; highlighted in red) and other begomoviruses from Brazil.

Several studies have shown that, as it occurs with cultivated plants, the diversity of begomovirus species associated with weeds is high, especially those belonging to the families Malvaceae, Solanaceae and Fabaceae (Castillo-Urquiza et al., 2008; Silva et al., 2012; Tavares et al., 2012). Standing out among the malvae, members of the genera sida and Abutilon show wide begomovirus genetic diversity, and some cultivated species are also infected by this virus group (Castillo-Urquiza, et al., 2008; Tavares et al., 2012; Wyant et al., 2012; Albuquerque et al., 2013).

In Brazil, Sida spp. have been frequently described as hosts for several begomovirus species, and may play an important epidemiological role as a source of begomovirus for cultivated species, especially tomato plants (Castillo-Urquiza et al., 2008; Tavares et al., 2012). This hypothesis is reinforced by the detection of Sida micranta mosaic virus, SiMoV and Tomato mild mosaic virus occurring in both tomato plants and Sida spp. in field conditions (Castillo-Urquiza et al., 2007; Cotrim et al., 2007; Rocha et al., 2013).

Although this is the first report of a begomovirus infecting the wild species $G$. guerkeana (Malvaceae), this result indicates that this uncultivated plant may constitute an important reservoir and source of novel begomoviruses. However, additional studies are needed to evaluate the epidemiological role of these hosts for begomovirus outbreaks in cultivated species.

\section{References}

Albuquerque, L.C., Aranha, S.A., Fernandes, F.R., Inove-Nagata, A. K. 2013. Further evidence reveals that okra mottle virus arose from a double combination event. Achives of Virology 158:181186.

Barreto, S.S., Hallwass, M, Aquino, O.M., InoveNagata, A.K. 2013. A Study of Weeds as Potential Inoculum Sources for a Tomato-Infecting Begomovirus in Central Brazil. Phytopathology 103:436-444.

Brown, J.K., Fauquet, C.M., Briddon, R.W., Zerbini, F.M., Moriones, E. and Navas-Castillo, J. 2012. Family Geminiviridae. In: Virus Taxonomy: Classification and Nomenclature of Viruses Ninth Report of the International Committee on Taxonomy of Viruses, King, A.M.Q., M.J. Adams, E.B. Carstens and E.J. Lefkowitz, (Eds.). Elsevier Academic Press 351-373.

Brown, J.K., Zerbini, F.M., Navas-Castillo, J., Moriones, E., Ramos-Sobrinho, R., Silva, J.C., Fiallo-Olivé, E., Briddon, R.W., HernándezZepeda, C., Idris, A., Malathi, V.G., Martin, D.P., 
Rivera-Bustamante, R., Ueda, S., Varsani, A 2015. Revision of Begomovirus taxonomy based on pairwise sequence Comparisons. Archives of Virology 160:1593-1619.

Castillo-Urquiza, G.P., Beserra Junior, J.E.A., Alfenas-Zerbini, P., Varsani, A., Lima, A.T.M., Barros, D.R., Zerbini, F.M. 2007. Genetic diversity of begomoviruses infecting tomato in Paty do Alferes, Rio de Janeiro state, Brazil. Virus Reviews and Research 12:233.

Castillo-Urquiza, G.P., Beserra, J.E.A., Jr Bruckner, F.P., Lima, A.T.M., Varsani, A., Alfenas-Zerbini, P., Zerbini, F.M. 2008. Six novel begomoviruses infecting tomato and associated weeds in Southeastern Brazil. Archives of Virology 153:9851989.

Cotrim, M.A.A., Krause-Sakate, R., Narita, N., Zerbini, F. M., Pavan, M. A. 2007. Diversidade genética de begomovírus em cultivos de tomateiro no Centro-Oeste Paulista. Summa Phytopathologica 33:300-303.

Doyle J.J., Doyle J.L. 1987. A rapid DNA isolation procedure for small amounts of fresh leaf tissue. Phytochemical Bulletin 19:11-15.

Inove-Nagata, A.K., Albuquerque, L.C., Rocha, W.B., Nagata, T. 2004. A simple method for cloning of the complete begomovirus using the bacteriophage phi 29 DNA polymerase. Journal of Virological Methods 11:209-211.

Morales, F.J. 2010. Distribution and dissemination of begomoviruses in Latin America and the Caribbean: Bemisia. In: Stansly, P.A., Naranjo, S.E., (ed.) Bionomics and management of a global pest. Springer, London, United Kingdom p. 283-318.

Muhire, B., Martin, D.P., Brown, J.K., NavasCastillo, J., Moriones, E., Zerbini, F.M., RiveraBustamante, R., Malathi, V.G., Briddon, R.W. and 1 more. 2013. A genome-wide pairwise-identitybased proposal for the classification of viruses in the genus Mastrevirus (family Geminiviridae). Archives of Virology 158:1411-1424.

Navas-Castillo, J., Fiallo-Olivé, E., SánchezCampos, S. 2011. Emerging virus diseases transmitted by whiteflies. Annual Review of Phytopathology 49:219-248.

Rannala, B., Yang, Z. 1996. Probability distribution of molecular evolutionary trees: a new method of phylogenetic inference. Journal of Molecular Evolution 43:304-311.

Rocha, C.S., Castillo-Urquiza, G.P., Lima, A.T.M., Silva, F.N., Xavier, C.A.D., Hora-Júnior, B.T., BeserraJúnior, J.E.A., Malta, A.W.O., Martin, D.P. \& other authors. 2013. Brazilian begomovirus populations are highly recombinant, rapidly evolving, and segregated based on geographical location. Journal of Virology 87:5784-5799.

Ronquist, F., Teslenko, M., Van Der Mark, P., Ayres, D.L., Darling, A., Höhna, S., Larget, B., Liu, L., Suchard, M.A., Huelsenbeck, J.P. 2012. MrBayes 3.2: Efficient Bayesian Phylogenetic Inference and Model Choice across a Large Model Space. Systematic Biology Advance Access 61:539-42.

Silva, S.J.C., Castillo-Urquiza, G.P., Hora-Júnior, B.T., Assunção, I.P., Lima, G.S.A.; Pio-Ribeiro, G., Mizubuti, E.S.G., Zerbini, F.M. 2012. Species diversity, phylogeny and genetic variability of begomovirus populations infecting leguminous weeds in northeastern Brazil. Plant Pathology 61:457-467.

Tamura, K., Stecher, G., Peterson, D., Filipski, A., Kumar, S. 2013. MEGA6: Molecular Evolutionary Genetics Analysis Version 6.0. Molecular Biology and Evolution 30:2725-2729.

Tavares, S.S., Ramos-Sobrinho, R., GonzalezAguilera, J., Lima, G.S.A., Assunção, I.P., Zerbini, F.M. 2012. Further molecular characterization of weed-associated begomoviruses in Brazil with an emphasis on Sida spp. Planta Daninha 30:305315.

Varsani A, Roumagnac $P$, Fuchs $M$, NavasCastillo J, Moriones E, Idris A, Briddon RW, RiveraBustamante R, Murilo Zerbini FM, Martin DP (2017) Capulavirus and Grablovirus: two new genera in the family Geminiviridae. Archives of Virology 162:1819-1831

Zerbini FM, Briddon RW, Idris A, Martin DP, Moriones E, Navas-Castillo J, Rivera-Bustamante R, Roumagnac P, Varsani A, ICTV Report C (2017) ICTV Virus Taxonomy Profile: Geminiviridae. Journal of General Virology 98:131-133

Wyant, P.S., Strohmeier, S., Schäfer, B., Krenz, B., Assunção, I.P., Lima, G.S.A, Jeske, H. 2012. Circular DNA genomics (circomics) exemplified for geminiviruses in bean crops and weeds of northeastern Brazil. Virology 427:151-157. 